\title{
Bruselloz Hastalığının Değerlendirilmesinde Spesifik Testler ve Enflamatuvar Biyobelirteçler
}

\section{Specific Tests and Inflammatory Biomarkers in the Evaluation of Brucellosis Disease}

\author{
Ferhan $\operatorname{KERGET}^{1}(\mathrm{ID})$, Buğra KERGET²(ID), Neslihan ÇELiK${ }^{1}(\mathrm{ID})$, Sibel iBA YILMAZ1 (ID) \\ 1 Sağlık Bilimleri Üniversitesi Erzurum Bölge Eğitim ve Araştırma Hastanesi, Enfeksiyon Hastalıkları ve \\ Klinik Mikrobiyoloji Anabilim Dalı, Erzurum. \\ ${ }^{1}$ Health Sciences University Erzurum Regional Education and Research Hospital, Department of Infection Diseases and \\ Clinical Microbiology, Erzurum, Turkey. \\ ${ }^{2}$ Atatürk Üniversitesi Tıp Fakültesi, Göğüs Hastalıkları Anabilim Dalı, Erzurum. \\ ${ }^{2}$ Ataturk University Faculty of Medicine, Department of Pulmonology, Erzurum, Turkey.
}

Makale Atıfı: Kerget F, Kerget B, Çelik N, iba Yılmaz S. Bruselloz hastalığının değerlendirilmesinde spesifik testler ve enflamatuvar biyobelirteçler. Mikrobiyol Bul 2021;55(2):113-124.

\section{ÖZ}

Bruselloz dünyanın en yaygın bakteriyel zoonotik enfeksiyonu olup gelişmekte olan birçok ülkede hala endemik olarak görülmektedir. Brusellozun klinik görünümü özgül olmayıp enfeksiyonun seyri ve şiddeti değişkenlik göstermektedir. Bu çalışmada, Bruselloz hastalarında özgül laboratuvar parametrelerinin klinik yanıt ve organ tutulumu ile olan ilişkisinin tespit edilmesi amaçlanmıştır. Enfeksiyon Hastalıkları ve Klinik Mikrobiyoloji Kliniğine başvuran Brucella tüp aglütinasyon testleri pozitif ve kliniği Bruselloz ile uyumlu daha önceden Bruselloz geçirmemiş 100 hasta prospektif olarak değerlendirilmiştir. Hastalar başlangıçtan itibaren 1, 2 ve 6 . haftada kontrole çağırılmıştır. Kalça ağrısı ve bel ağrısı şikayeti olan hastalar sakroileit ve spondilodiskit açısından sakroiliak manyetik rezonans görüntüleme (MR) ve lomber MR ile değerlendirilmiştir. Karaciğer tutulumu, kemik iliği tutulumu, sakroileit, spondilodiskit ve orşit bulunan hastalar organ tutulumu olan hastalar olarak kaydedilmiştir. Altı hafta sonrasında şikayetlerin gerilemesi klinik yanıt olarak değerlendirilmiş, tedavinin 6. haftasında klinik yanıt alınan hastalarda trombosit dağııım genişliği (TDG) ve ortalama trombosit hacmi (OTH) düzeyinin klinik yanıt alınmayan hastalara göre istatistiksel olarak anlamlı düzeyde düşük olduğu gözlenmiştir $(p=0.01, p=0.02)$. Organ tutulumu olan hastalarda trombosit ve trombosit lenfosit oranı (TLO) düzeyinin tedavinin 1. ve 6. haftasında organ tutulumu olmayan hastalara göre istatistiksel olarak anlamlı düzeyde düşük olduğu gözlenmiştir (1. hafta: $p=0.001$, $p=0.01 ; 6$. hafta $p=0.03, p=0.01)$. Organ tutulumu olan ve olmayan hastalar arasında tedavinin başlangıcındaki TLO'ya yönelik yapılan alııı işlem karakteristikleri "Receiver Operating Characteristic (ROC)" eğrisi analizinde eğri altında kalan alan \%66 olarak saptanmıştır. Eşik değeri 128.8 alındığında duyarııık \%55, özgüllük ise \%78 olarak tespit edilmiştir. Tedavinin başlangıcındaki trombosit düzeyine göre organ tutulumu olan ve olmayan hastalar arasında yapılan ROC eğrisi analizinde ise eğri altında kalan alan $\% 73$, eşik değeri 256000 alındığında duyarııık \%71, özgüllük ise \%68 olarak gözlenmiştir. Tedavinin 6. haftasında klinik yanıt alınan ve alınmayan hastalar arasında TDG düzeyinin yapılan ROC eğrisi analizinde ise eğri altında kalan alan \%67 olarak gözlenmiştir. Eşik değeri 10.75 alındığında duyarılık \%65, özgüllük ise \%70 olarak saptanmıştır . OTH değerinin klinik yanıt için yapılan ROC eğrisi analizinde ise eğri altında 
kalan alan \%66; eşik değeri 9.95 alındığında ise duyarlılı̆ı \%52, özgüllüğü \%74 olarak gözlenmiştir. Sonuç olarak, Bruselloz tanısı olan hastalarda tedavinin sonlandırılmasında önemli yer tutan klinik yanıtın değerlendirilmesinde OTH ve TDG değerlerinin kullanımının; organ tutulumunun değerlendirilmesinde ve takibinde ise trombosit düzeyi ve TLO değerlerinin klinik olarak kullanılabilecek ucuz, kolay erişilebilir biyobelirteçler olduğu belirlenmiştir.

Anahtar kelimeler: Bruselloz; trombosit dağılım genişliği; trombosit lenfosit oranı; sakroileit; orşit.

\section{ABSTRACT}

Brusellosis is the world's most common bacterial zoonotic infection and is still endemic in many developing countries. The clinical appearance of brucellosis is not specific, but the course and severity of the infection varies. In this study, it was aimed to determine the relationship between laboratory parameters and clinical response and organ involvement in patients with Brucellosis diagnosed with specific diagnostic tests. In the study, 100 patients without previous diagnosis of Brucellosis who have admitted to the Department of Infectious Diseases and Clinical Microbiology and had positive Brucella tube agglutination tests and whose clinic was compatible with Brucellosis were evaluated prospectively. Patients were invited to be checked in the $1^{\text {st }}, 2^{\text {nd }}$ and $6^{\text {th }}$ weeks. Patients with hip pain and low back pain were evaluated with sacroiliac magnetic resonance imaging (MRI) and lumbar MRI for sacroiliitis and spondylodiscitis. Patients with liver and bone marrow involvements, sacroiliitis, spondylodiscitis and orchitis were recorded as the patients with organ involvement. After six weeks, the decline of the complaints was considered as a clinical response. In the $6^{\text {th }}$ week of the treatment, it was observed that platelet distribution width (PDW) and mean platelet volume (MPV) levels were lower in patients with a clinical response compared to the patients with no clinical response which was statistically significant $(p=0.01$, $p=0.02$ ). Platelet and platelet lymphocyte ratio (PLR) level in patients with organ involvement in the $1^{\text {st }}$ and $6^{\text {th }}$ weeks of the treatment, were observed to be lower than the patients without organ involvement which was statistically significant (week $1: p=0.001, p=0.01$; week $6: p=0.03, p=0.01$ ). Among patients with organ involvement and non-organ involvement, the area under the curve was $66 \%$ in the ROC curve analysis for PLR at the onset of the treatment. When the cut-off value was taken as $128.8 \%$, the sensitivity was $55 \%$, and the specificity was $78 \%$. Depending on the level of platelet at the beginning of the treatment, in the ROC curve analysis carried out among patients with organ involvement and non-organ involvement, the area under the curve was $73 \%$ and when the cut off value was taken as 256000 , the sensitivity was $71 \%$, and the specificity was $68 \%$. In the $6^{\text {th }}$ week of the treatment, the area under the curve was observed as $67 \%$ in the ROC curve analysis of the PDW level among patients from whom clinical responses were received and not received. When the cut-off value was taken as $10.75 \%$, the sensitivity was $65 \%$, and the specificity was $70 \%$. In the ROC curve analysis of the MPV value for clinical response, the area under the curve was $66 \%$, and when the cut-off value was taken as 9.95 , the sensitivity was observed as $52 \%$, and the specificity was $74 \%$. As a result, in the evaluation of the clinical response, which is important in the termination of the treatment in patients with Brucellosis, the use of MPV and PDW values in the evaluation of organ involvement and platelet level and PLO in the follow up, are cheap, easily accessible biomarkers that can be used clinically.

Keywords: Brusellosis; platelet distribution width; platelet lymphocyte ratio; sacroiliitis; orchitis.

\section{Giriş}

Bruselloz dünyanın en yaygın bakteriyel zoonotik enfeksiyonu olup gelişmekte olan birçok ülkede hala endemik olarak görülmektedir. Brusellozun klinik görünümü özgül olmayıp enfeksiyonun seyri ve şiddeti değişkenlik göstermektedir. İnkübasyon süresi 2-3 haftadır. Bulaşma genellikle gastrointestinal sistem, konjonktiva, cilt ve solunum yolu ile olmaktadır. En yaygın semptomlar yüksek ateş, huzursuzluk, iştahsızlık, terleme, kas ve eklem ağrılarıdır. Bakteri retiküloendotelyal sistem organlarına yüksek bir afiniteye sahiptir $^{1}$. Akut Brusellozda anemi, trombositopeni ve lökopeni gibi hematolojik komplikasyon- 
lar sıklıkla bildirilmesine rağmen şiddetli trombositopeni görülmesi nadirdir ${ }^{2,3}$. Hipersplenizim, reaktif hemofagositoz ve immünsupresyon trombositopeninin olası nedenleri olarak gösterilmiştir ${ }^{4}$. Tanı; klinik bulgular, kültür sonuçları ve serolojik testler yardımı ile konulmaktadır ${ }^{5}$. Aynı zamanda akut faz yanıtına bağlı akut faz reaktanlarında artış ve azalış olabilmesine rağmen normal seyirlerde de görülebilmektedir ${ }^{6,7}$.

Son zamanlarda bilimsel ilerlemelere rağmen, endemik bölgelerde Brusellozu teşhis etmek, tedavi etmek ve izlemek hala zordur. Tedavi süresi en az altı hafta olarak planlanmaktadır ${ }^{8}$. Sakroileit, spondilodiskit, orşit ve nörobruselloz gibi organ tutulumlarında en az üç ay olarak tedavi bildirilmektedir ${ }^{9,10}$. Ancak tedavi sonlandırıldıktan sonra hastaların eklem ağrısı şikayetleri devam edebilmektedir. Brucella tanısına özgül testler tedavi sonrasında uzun bir süre pozitif olarak kalabilmektedir ${ }^{11}$. Bu nedenle hastaların laboratuvar sonuçları tam olarak değerlendirilememekte ve tedavi süresinin yeterliliğine karar vermekte oldukça güç olmaktadır. Bu durum tedavi yanıtının ve süresinin değerlendirilmesinde kolay çalışııır, ucuz biyobelirteçlere gereksinim duyulmasına neden olmuştur.

Bu çalışmada, özgül tanısal testlerle tanı konulmuş Bruselloz hastalarında laboratuvar parametrelerinin klinik yanıt ve organ tutulumu ile olan ilişkisinin tespit edilmesi amaçlanmıştır.

\section{GEREÇ ve YÖNTEM}

Bu çalışma, Erzurum Bölge Eğitim ve Araştırma Hastanesi Etik Kurulunun onayı ile gerçekleştirildi (Karar No: 2019/10-103, Tarih: 01.07.2019).

Hastanemiz Enfeksiyon Hastalıkları ve Klinik Mikrobiyoloji Kliniğine başvuran Brucella tüp aglütinasyon testleri pozitif ve kliniği Bruselloz ile uyumlu daha önceden Bruselloz geçirmemiş 100 hasta prospektif olarak değerlendirildi. Kesin tanı klinik belirtileri olan hastalarda Rose Bengal test pozitifliği Brucella tüp aglütinasyon test pozitifliği ( $\geq 1 / 160)$ ile konuldu. Hastaların yaş, cinsiyet, tam kan sayımı, trombosit, ortalama trombosit hacmi (OTH), trombosit dağılım genişliği (TDG), eritrosit dağılım genişliği (RDW), nötrofil lenfosit oranı (NLO), trombosit lenfosit oranı (TLO), sedimantasyon hızı (ESR), C-reaktif protein (CRP), aspartat aminotransferaz (AST), alanin aminotransferaz (ALT), kreatin kinaz (CK), laktat dehidrogenaz (LDH), albümin, serum tüp aglütinasyon testleri ve Brucella IgM, Brucella IgG sonuçları tedavi başlangıçlarında ve 6 hafta sonunda kaydedildi. Hastalar başlangıçtan itibaren 2. ve 6. haftada kontrole çağrıldı. Klinik bulgularına ek olarak başlangıçta bakılan laboratuvar parametreleri de kaydedildi. Hastaların ateş, terleme, halsizlik, kilo kaybı, miyalji, baş ağrısı, eklem ağrısı, bulantı, kusma, ishal, kalça ağrısı, bel ağrısı, döküntü şikayetleri sorgulandı ve ilk gelişlerinde, iki hafta sonra ve altı hasta sonra tekrar sorgulanarak kaydedildi. Altı hafta sonrasında şikayetlerin gerilemesi klinik yanıt olarak değerlendirildi. Kalça ağrısı ve bel ağrısı şikayeti olan hastalar sakroileit ve spondilodiskit açısından sakroiliak MR ve lomber MR ile değerlendirildi. Karaciğer tutulumu, kemik iliği tutulumu, sakroileit, spondilodiskit ve orşit bulunan hastalar organ tutulumu olan hastalar olarak kaydedildi. Başka bir nedene bağlı olmaksızın karaciğer enzimleri yükselen hastalar karaciğer tutulumu olarak lökopeni, trombositopeni ve anemi izlenen 
hastalar kemik iliği tutulumu olarak değerlendirildi. Ürogenital şikayetleri olan erkek hastalarda orşit tanısı Doppler ultrasonografi ile konuldu. Kronik enflamatuvar hastalık öyküsü olanlar, Bruselloz dışında enfeksiyonu olanlar, sistemik hastalığı olanlar ve uzun süreli ilaç kullanımı olanlar çalışmaya dahil edilmedi.

\section{İstatistiksel Analiz}

İstatistiksel analiz, SPSS for Windows (sürüm 22.0; SPSS Inc., Chicago, III., ABD) ile yapıldı. Parametrik verilerin gruplar arasında karşılaştırılmasında Pearson ki-kare testi kullanıldı; normal dağılmayan sayısal verilerin gruplar arası karşılaştırmalarında MannWhitney $U$ testi kullanıldı. Grupların demografik verileri ve laboratuvar parametreleri bağımsız örnekler t testi kullanılarak değerlendirildi. Pearson korelasyon analizi; CRP ile OTH, TDG sonuçları arasında ve TLO ile ALT, alkalen fosfataz (ALP) sonuçları arasında kullanıldı. TLO, trombosit düzeyinin tedavinin başında, OTH ve TDG düzeyinin ise tedavinin 6. haftasında duyarlılık ve özgüllüğünün tespitinde ROC eğrisi analizi kullanıldı.

\section{BULGULAR}

Çalışmaya alınan hastaların yaş ortalaması $42.3 \pm 14.9$ olarak belirlenmiştir. Hastaların 61'i erkek, 39'u ise kadın olarak tespit edilmiştir. Hastaların tedavi başlangıcı, 2 ve 6.

\begin{tabular}{|c|c|c|c|c|c|}
\hline & $\begin{array}{l}\text { 1. hafta } \\
\text { (Ort } \pm \text { SD) }\end{array}$ & $\begin{array}{l}\text { 2. hafta } \\
\text { (Ort } \pm \text { SD) }\end{array}$ & $\begin{array}{l}\text { 6. hafta } \\
\text { (Ort } \pm \text { SD) }\end{array}$ & $\mathrm{p}^{*}$ & $p^{* *}$ \\
\hline WBC $(/ \mu \mathrm{l})$ & $6865.2 \pm 1909.2$ & $6846.6 \pm 1741.1$ & $6695.1 \pm 1672.8$ & 0.737 & 0.176 \\
\hline Hemoglobin (g/dl) & $14.7 \pm 1.5$ & $14.7 \pm 1.6$ & $14.9 \pm 1.6$ & 0.828 & 0.033 \\
\hline Trombosit (/L) & $269350 \pm 78873$ & $275110 \pm 71769.3$ & $260650 \pm 64717.8$ & 0.5 & 0.001 \\
\hline TDG (fL) & $11.1 \pm 1.8$ & $11.3 \pm 1.7$ & $11.2 \pm 1.6$ & 0.006 & 0.39 \\
\hline OTH (fL) & $9.8 \pm 0.9$ & $9.9 \pm 0.8$ & $9.9 \pm 0.8$ & 0.019 & 0.974 \\
\hline $\mathrm{NLO}$ & $1.97 \pm 1.27$ & $1.9 \pm 1.9$ & $1.7 \pm 0.9$ & 0.012 & 0.639 \\
\hline RDW (\%) & $13.2 \pm 1.6$ & $13.4 \pm 1.7$ & $13.7 \pm 1.4$ & 0.44 & 0.004 \\
\hline TLO & $132.1 \pm 53.4$ & $131.1 \pm 84.3$ & $120.7 \pm 46.3$ & 0.151 & 0.188 \\
\hline CRP (mg/L) & $13.1 \pm 15.7$ & $5.3 \pm 5.8$ & $3.5 \pm 1.5$ & 0.001 & 0.001 \\
\hline AST $(U / L)$ & $48.3 \pm 131.6$ & $24.7 \pm 15.3$ & $22.3 \pm 12.1$ & 0.004 & 0.01 \\
\hline $\operatorname{ALT}(\mathrm{U} / \mathrm{L})$ & $48.9 \pm 110.8$ & $29.3 \pm 35.8$ & $25.3 \pm 25.6$ & 0.001 & 0.021 \\
\hline GGT (U/L) & $41.1 \pm 40.5$ & $37.4 \pm 32.7$ & $38.9 \pm 65.7$ & 0.316 & 0.487 \\
\hline $\operatorname{ALP}(\mathrm{U} / \mathrm{L})$ & $98.4 \pm 42.8$ & $90.4 \pm 35.1$ & $83.8 \pm 27.6$ & 0.002 & 0.001 \\
\hline $\mathrm{LDH}(\mathrm{U} / \mathrm{L})$ & $253.2 \pm 190.2$ & $192.7 \pm 77.7$ & $157.4 \pm 54.9$ & 0.001 & 0.001 \\
\hline Albümin (g/L) & $4.2 \pm 0.4$ & $4.3 \pm 0.3$ & $4.3 \pm 0.3$ & 0.256 & 0.774 \\
\hline
\end{tabular}

WBC: Beyaz kan hücresi, TDG: Trombosit dağılım genişliği, OTH: Ortalama trombosit hacmi, NLO: Nötrofil lenfosit oranı, RDW: Kırmızı kan hücresi dağılım genişliği, TLO: Trombosit lenfosit oranı, CRP: C-reaktif protein, AST: Aspartat aminotransferaz, ALT: Alanin aminotransferaz, GGT: Gama glutamil transferaz, ALP: Alkalen fosfataz, LDH: Laktat dehidrogenaz.

$\mathrm{p}^{*}$ : Hastaların 1. ve 2. haftadaki laboratuvar verilerinin karşılaştırılması.

$\mathrm{p}^{\star *}$ : Hastaların 2. ve 6. haftadaki laboratuvar verilerinin karşılaştırılması. 


\begin{tabular}{|c|c|c|c|}
\hline & $\begin{array}{l}\text { Tedavinin 6. haftasında klinik } \\
\text { yanıt var }(n=74)(\text { Ort } \pm \text { SD) }\end{array}$ & $\begin{array}{l}\text { Tedavinin 6. haftasında klinik } \\
\text { yanıt yok }(n=36)(\text { Ort } \pm \text { SD) }\end{array}$ & $\mathbf{p}$ \\
\hline Yaş & $41.4 \pm 14.6$ & $45.3 \pm 15.7$ & 0.242 \\
\hline WBC $(/ \mu \mathrm{l})$ & $6798.9 \pm 1695.2$ & $6399.6 \pm 1602.5$ & 0.287 \\
\hline Hemoglobin (g/dl) & $14.9 \pm 1.6$ & $14.8 \pm 1.5$ & 0.7 \\
\hline Trombosit (/L) & $262905.4 \pm 69431.4$ & $254230.8 \pm 49513.9$ & 0.495 \\
\hline TDG (fL) & $11.4 \pm 1.6$ & $10.5 \pm 1.1$ & 0.01 \\
\hline OTH (fL) & $9.9 \pm 0.8$ & $9.6 \pm 0.6$ & 0.02 \\
\hline NLO & $1.8 \pm 0.9$ & $1.5 \pm 0.7$ & 0.202 \\
\hline RDW (\%) & $13.8 \pm 1.4$ & $13.5 \pm 1.3$ & 0.267 \\
\hline TLO & $123 \pm 48.9$ & $114.3 \pm 37.9$ & 0.356 \\
\hline Sedimantasyon $(\mathrm{mm} / \mathrm{h})$ & $8.9 \pm 9.5$ & $12.7 \pm 12$ & 0.155 \\
\hline CRP (mg/L) & $3.5 \pm 1.6$ & $3.4 \pm 0.9$ & 0.766 \\
\hline AST (U/L) & $22.7 \pm 13.2$ & $21.2 \pm 7.9$ & 0.504 \\
\hline $\operatorname{ALT}(\mathrm{U} / \mathrm{L})$ & $25.5 \pm 28.7$ & $24.7 \pm 14.2$ & 0.858 \\
\hline GGT (U/L) & $39.2 \pm 75.1$ & $37.9 \pm 25.1$ & 0.896 \\
\hline $\operatorname{ALP}(\mathrm{U} / \mathrm{L})$ & $83.1 \pm 27.8$ & $85.9 \pm 27.4$ & 0.653 \\
\hline $\mathrm{LDH}(\mathrm{U} / \mathrm{L})$ & $156.9 \pm 50.2$ & $158.8 \pm 67.6$ & 0.892 \\
\hline Albümin (g/L) & $4.3 \pm 0.3$ & $4.2 \pm 0.3$ & 0.08 \\
\hline
\end{tabular}

haftadaki laboratuvar verileri Tablo I'de gösterilmiştir. Tedavinin 6. haftasında klinik yanıt tanımlamamıza göre yanıt alınan ve alınmayan hastaların yaşları ve laboratuvar verileri Tablo II'de gösterilmiştir. Tedavinin 6. haftasında klinik yanıt alınan hastalarda TDG ve OTH düzeyinin klinik yanıt alınmayan hastalara göre istatistiksel olarak anlamlı düzeyde yüksek olduğu gözlenmiştir ( $p=0.01, p=0.02)$.

Organ tutulumu, organ tutulumları arasında sakroileit olan ve olmayan hastaların tedavi başlangıcı ve 6 . haftada laboratuvar verilerinin değerlendirilmesi ise Tablo III ve IV'te gösterilmiştir. Organ tutulumu olan hastalarda trombosit ve TLO düzeyinin tedavinin 1. ve 6. haftasında organ tutulumu olmayan hastalara göre istatistiksel olarak anlamlı düzeyde düşük olduğu gözlenmiştir ( 1 . hafta: $p=0.001, p=0.01 ; 6$. hafta $p=0.03, p=0.01$ ).

Hastaların tedavinin başlangıcında bakılan OTH ile CRP düzeyleri arasında düşük düzeyli negatif yönlü korelasyon, TDG ile CRP düzeyi arasında ise orta düzeyli negatif yönlü korelasyon gözlenmiştir ( $r=-0.376, p=0.01 ; r=-0.422, p=0.01)$ (Şekil 1).

Tedavinin 6. haftasında bakılan TLO ile ALT ve ALP sonuçları arasında düşük düzeyli negatif yönlü korelasyon gözlenmiştir ( $r=-0.266, p=0.01 ; r=-0.204, p=0.01)$ (Şekil 2). 


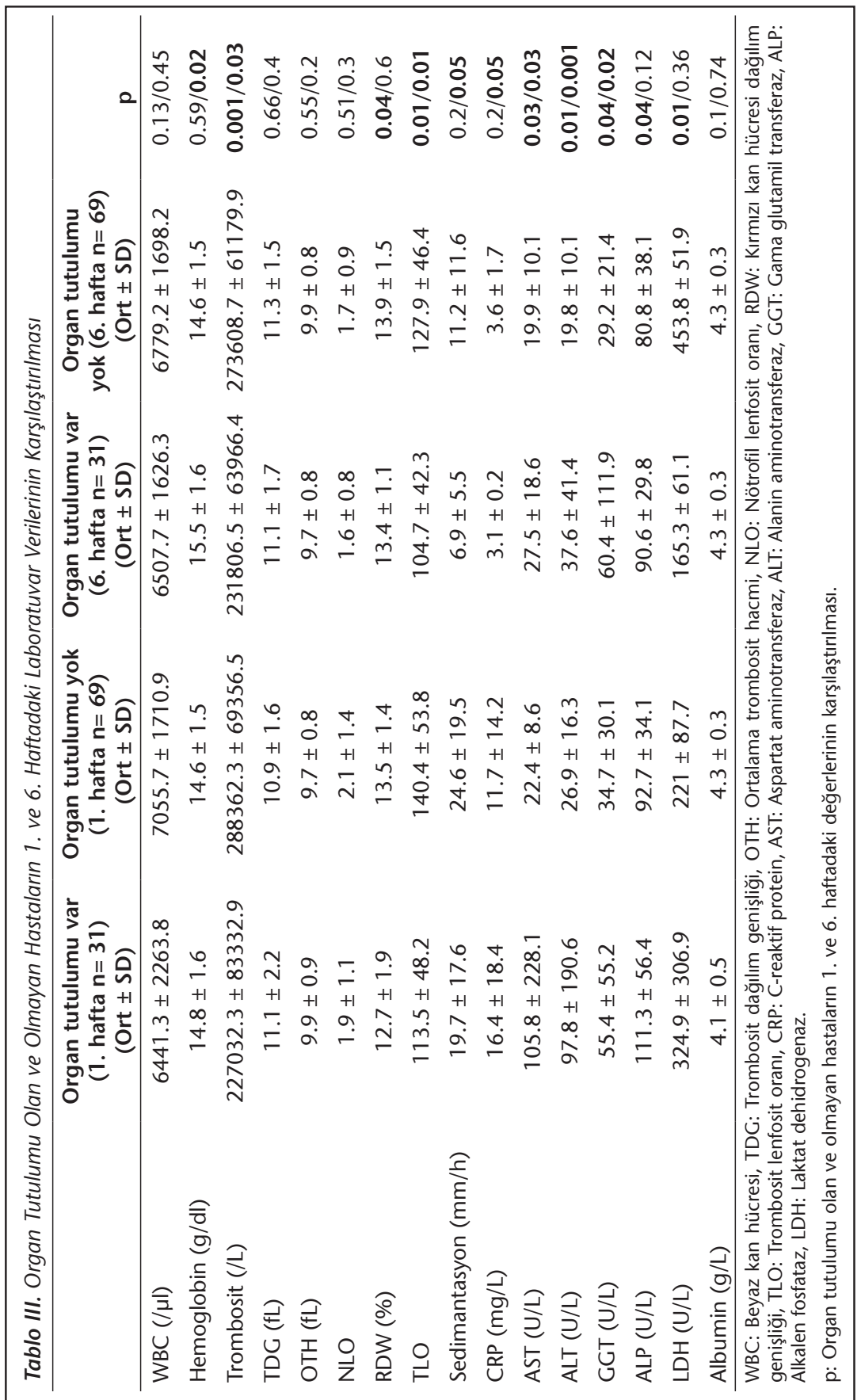




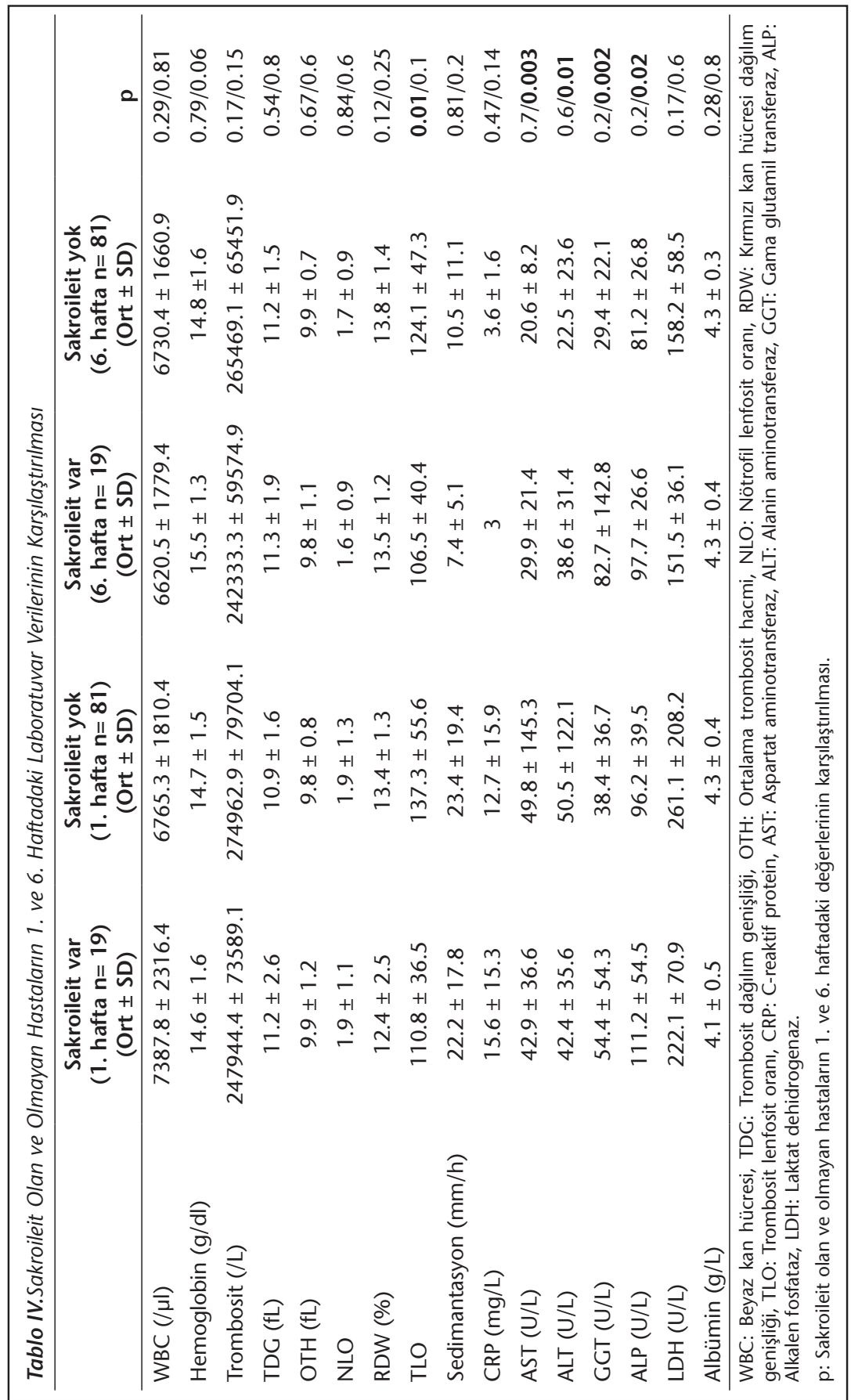




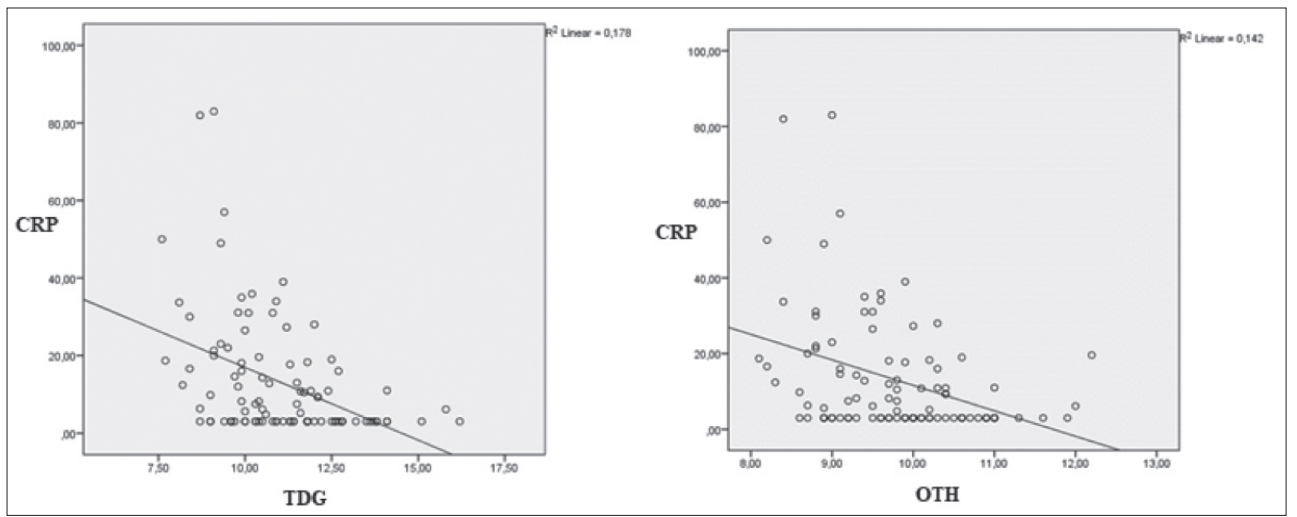

Şekil 1. CRP düzeyinin hastaların 1. haftadaki TDG ve OTH ile korelasyon analizi.

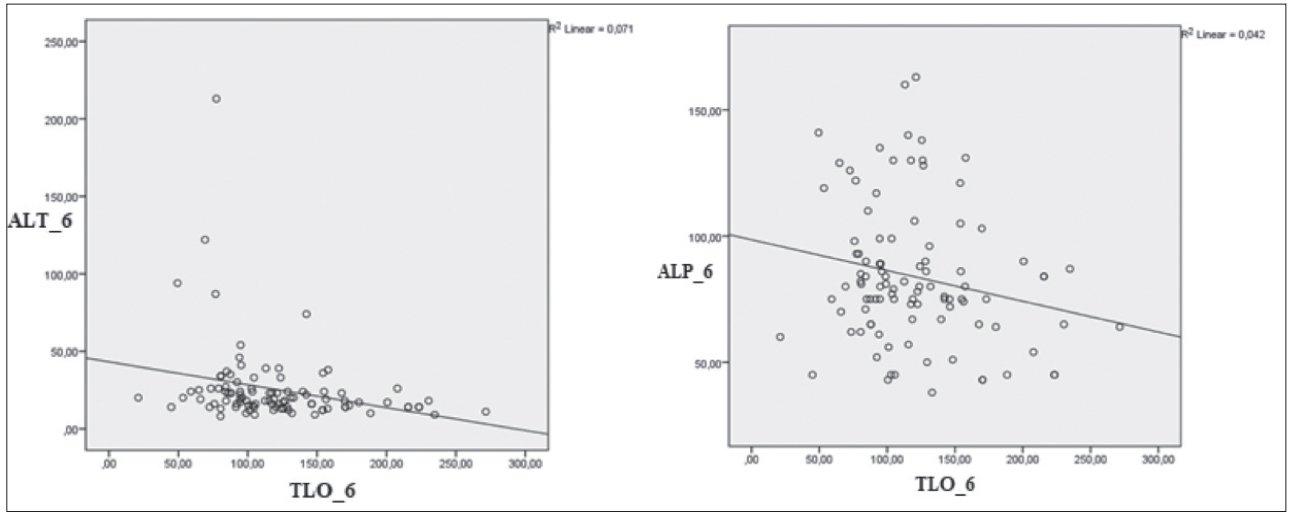

Şekil 2. Hastaların 6. haftadaki ALT ve ALP düzeylerinin TLO düzeyi ile yapılan korelasyon analizi.

Organ tutulumu olan ve olmayan hastalar arasında tedavinin başlangıcındaki TLO sonuçlarına yönelik yapılan ROC eğrisi analizinde eğri altında kalan alan \%66 olarak bulunmuştur. Eşik değeri 128.8 alındığında duyarlılık \%55, özgüllük ise \%78 olarak tespit edilmiştir. Tedavinin başlangıcındaki trombosit düzeyine göre organ tutulumu olan ve olmayan hastalar arasında yapılan ROC eğrisi analizinde ise eğri altında kalan alan \%73, trombosit düzeyi eşik değeri 256000 alındığında duyarlılık \%71, özgüllük ise \%68 olarak gözlenmiş̧tir (Şekil 3).

Tedavinin 6. haftasında klinik yanıt alınan ve alınmayan hastalar arasında TDG düzeyinin yapılan ROC eğrisi analizinde ise eğri altında kalan alan \%67 olarak gözlenmiştir. Eşik değeri 10.75 alındığında duyarlılığı \%65, özgüllüğü ise \%70 bulunmuştur. OTH değerinin klinik yanıt için yapılan ROC eğrisi analizinde ise eğri altında kalan alan \%66, eşik değeri 9.95 alındığında ise duyarlılığı \%52, özgüllüğü \%74 olarak gözlenmiştir (Şekil 4). 


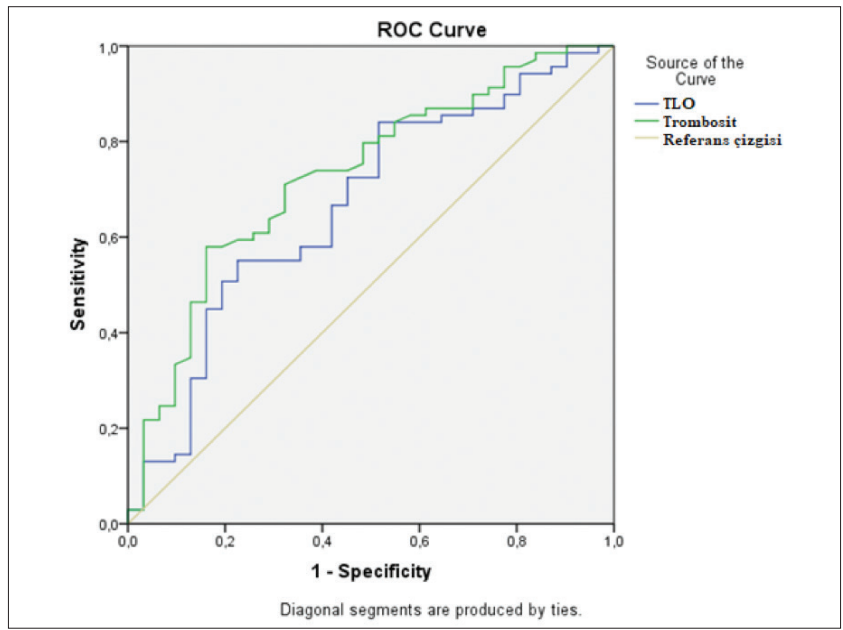

Şekil 3. Organ tutulumu olan ve olmayan hastaların trombosit ve TLO düzeylerinin ROC eğrisi analizi.

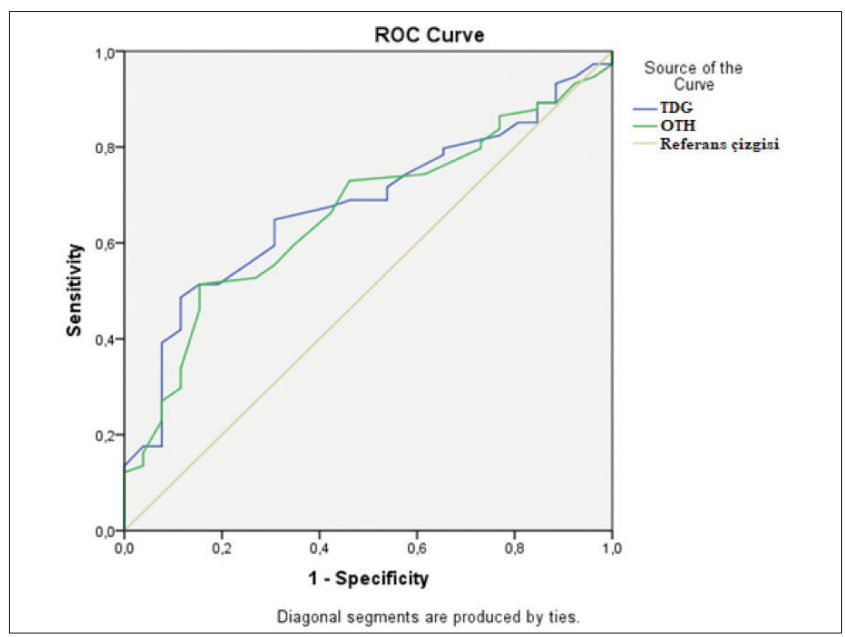

Şekil 4. Tedavinin 6. haftasında klinik yanıt alınan ve alınmayan hastaların TDG ve OTH düzeylerinin ROC eğrisi analizi.

\section{TARTIŞMA}

Bu çalışmada, tedavinin başlangıcında bakılan CRP düzeyi ile OTH ve TDG düzeyleri arasında negatif yönlü korelasyon gözlenmiştir. Tedavinin 6. haftasında klinik yanıt alınan ve alınmayan hastalar arasında OTH ve TDG düzeyleri karşılaştırıldığında klinik yanıt alınan hastalarda daha yüksek düzeyde olduğu gözlemlenmiştir. Tedavinin 6. haftasında TDG düzeyinin eşik değer 10.75 alınması durumunda duyarlılık \%65, özgüllük ise \%70 olarak gözlenirken, OTH'nin eşik değeri 9.95 alınması durumunda ise duyarlııı \%55, özgüllük ise \%74 olarak gözlenmiştir. TLO ve trombosit düzeyinin organ tutulumu olan 
ve olmayan hastalar arasındaki değerlendirmesinde organ tutulumu olan hastalarda daha düşük düzeyde TLO ve trombosit düzeyleri gözlemlenmiştir. Tedaviyle beraber ise, her iki grupta da TLO ve trombosit düzeylerinin yükseldiği ancak organ tutulumu olan grupta yine daha düşük olduğu belirlenmiştir.

Bruselloz, tüm organ ve sistemleri etkileyebilen dünyadaki en önemli zoonozların başında gelmektedir. Farkıı klinik ve laboratuvar bulguları ile çeşitli hastalıkları taklit edebilmektedir. Brusellozda tedavi süresi en az altı hafta olarak önerilmektedir ancak hastaların tedavi sonrası şikayetleri devam edebilmekte ve tedavilerinin sonlandırıması kolay olmamakta ve Bruselloza özgül testler tedavi sonrasında da uzun bir süre pozitif kalabilmekte$\operatorname{dir}^{12}$. Bunun yanı sıra Bruselloza bağlı gelişen organ tutulumlarının değerlendirilmesinde kullanılabilecek spesifik labaratuvar tanı ve testleri de bulunmamaktadır. Organ tutulumları da Brusellozda tedavinin yönetilmesinde önemli bir yer tutmaktadır ${ }^{13}$. Bu durum, Bruselloz takibinde alternatif parametrelerin araştırılmasına neden olmuştur.

Enflamasyon, endojen ve ekzojen kaynaklı uyarılaranlara karşı organizmanın verdiği özgül olmayan bir yanıttır. Bruselloz gibi bulaşııı hastalıklar ve doku yaralanmaları klasik enflamasyon başlatııılarındandır ${ }^{14}$. Bunların yanı sıra, çeşitli fizyolojik ve patolojik süreçler de enflamasyonu tetikleyebilir ve tüm bu uyaranlara yanıt benzer niteliktedir. Mast hücreleri ve makrofajlar tarafından salınan enflamatuvar mediatörler enflamasyonda önemli rol oynayan plazma proteinlerinin ve lökositlerin aktive olmasına araclık eder ${ }^{15}$. Ayrıca, bu aracılar megakaryositleri indükleyerek trombositoza da neden olabilir ${ }^{16}$. Ancak, Bruselloz hastalarında bunun tam tersi olarak trombositopeni de $\% 10$ olguda rapor edilmiştir ${ }^{17}$. Enflamasyonun modüle edilmesinde lenfositler önemli rol oynamaktadır. Sistemik enflamasyonda önemli rol oynayan lenfositlerin artan apoptozisine bağlı olarak lenfositopeni gelişebilmektedir; nötrofiller yanıtın yetersiz olması ve kronik enflamasyonun başlaması durumunda lenfosit ve makrofajların yerini alır. Sonuç olarak, sistemik enflamasyona bağlı lenfosit, nötrofil ve trombosit düzeylerinde değişiklilikler gözlenir ${ }^{18}$.

Pediyatrik Bruselloz artritli hastalarda yapılan çalışmalarda NLO düzeyinin kontrol grubu ile yapılan karşılaşııımasında Bruselloz gözlenen hastalarda anlamlı düzeyde yüksek tespit edilmiştir ${ }^{19}$. Bruselloza bağlı komplikasyonların ve organ tutulumunun değerlendirildiği bir başka çalışmada ise, TLO'nun NLO'ya nazaran organ tutulumunu ve komplikasyonları göstermede daha etkili bir biyobelirteç olduğu tespit edilmiştir ${ }^{20}$. Proenflamatuvar sitokinlerin ve akut faz reaktanlarının salınımı trombositlerin boyutlarını da değiştirebilmektedir. OTH ve TDG'nin trombosit üretiminde ve fonksiyonunun değerlendirilmesinde yararlı olabileceği gözlenmiştir Brusellozlu hastalarda yapılan çalışmalarda tanı anında gözlenen OTH değerinin tedavi ile birlikte düzeyinde yükselme olduğu gözlenmiştir ${ }^{21}$. CRP düzeyinin OTH ile korelasyonunun değerlendirildiği çalışmalarda, elde edilen veriler çelişkili nitelikte olup pozitif ve negatif korelasyonun bulunduğu gözlenmiştir ${ }^{21,22}$.

Çalışmamız verileri doğrultusunda, karaciğer fonksiyon testleri ve akut faz reaktantları dışındaki parametrelerin tedavi altındaki hastaların takiplerinde yol gösterici olmadığı izlenmiş ancak hastalar klinik yanıtlarına göre ayrıldığında klinik yanıt olan hastalarda daha 
yüksek düzeyde OTH ve TDG düzeyleri gözlemlenmiştir. Bu durum yapılan çalışmalarla birlikte değerlendirildiğinde, klinik yanıta bağlı düzelen trombosit üretiminin OTH ve TDG düzeyini daha fazla artırdığını düşündürmektedir. Organ tutulumu olan ve olmayan hastaların 1. ve 6. hafta değerlendirilmelerinde, organ tutulumu olan hastalarda her iki dönemde de daha düşük trombosit ve TLO oranı gözlemlenmiş, TLO ve trombosit düzeyleri ise takiplerle beraber her iki hasta grubunda da gerilemiştir. Sakroileit olan hastalarda ise başlangıçta düşük gözlenen TLO oranın 6. haftada olmayan grup ile karşılaştırmasında istatistiksel olarak anlamlı fark gözlenmiştir. Bu veriler trombosit düzeyi, hacmi ve yoğunluğunun TLO oranı ile korele değerlendirilmesinde klinik yanıt ve organ tutulumu açısından değerlendirilmesinde diğer parametrelere göre daha üstün olduğu yönünde değerlendirilebilir. Organ tutulumu ve klinik yanıt olan ve olmayan hastaların yapılan ROC analizinde ise, TLO ve trombosit ile TDG ve OTH düzeylerinin duyarlılık ve özgüllüklerinin birbirine karşılıklı üstün olması nedeniyle organ tutulumu değerlendirilmesinde birlikte değerlendirilmesi daha uygun olabilir.

Çalışmamızda hem klinik düzelmenin takibinde hem de organ tutulumunun değerlendirilmesinde trombosit düzeyi, dağılım genişliği ve ortalama hacminin önemli rol oynadığı gözlemlenmiş̧tir. Ancak bu parametrelerin değerlendirmesinde özgüllüğün yüksek olup, duyarlılıkların düşük olması nedeniyle, ön planda duyarılığı daha yüksek olan trombosit ile ilişkili parametrelerin bulunması Bruselloz takibinde önemli bir rol oynayabilir.

Sonuç olarak, Brusellozlu hastalarda tedavinin sonlandırılmasında önemli yer tutan klinik yanıtın değerlendirilmesinde OTH ve TDG'nin kullanımı, organ tutulumunun değerlendirilmesinde ve takibinde ise trombosit düzeyi ve TLO klinik olarak kullanılabilecek ucuz, kolay erişilebilir biyobelirteçler olabilirler.

\section{ETIK KURUL ONAYI}

Bu çalışma, Erzurum Bölge Eğitim ve Araştırma Hastanesi Etik Kurulunun onayı ile gerçekleştirildi (Karar No: 2019/10-103, Tarih: 01.07.2019).

\section{ÇIKAR ÇATIŞMASI}

Yazarlar bu makale ile ilgili herhangi bir çıkar çatışması bildirmemişlerdir.

\section{KAYNAKLAR}

1. Mantur B, Amarnath S, Shinde R. Review of clinical and laboratory features of human brucellosis. Indian J Med Microbiol 2007; 25(3): 188.

2. Young EJ, Tarry A, Genta RM, Ayden N, Gotuzzo E. Thrombocytopenic purpura associated with brucellosis: report of 2 cases and literature review. Clin Infect Dis 2000; 31(4): 904-9.

3. Aysha MH, Shayib MA. Pancytopenia and other haematological findings in brucellosis. Scand J Haematol 1986; 36(4): 335-8.

4. Pappas G, Kitsanou M, Christou L, Tsianos E. Immune thrombocytopenia attributed to brucellosis and other mechanisms of Brucella-induced thrombocytopenia. American J Haem 2004; 75(3): 139-41.

5. İrvem A, Yücel FM, Aksaray S, Bor E. Brusellozun serolojik tanısında yeni ve hızlı bir yöntem olan brucella coombs jel testi ile diğer yöntemlerin karşılaştırılması. Mikrobiyol Bul 2015; 49(2): 181-7. 
6. Percin D. Microbiology of brucella. Recent patents on anti-infective drug discovery. 2013; 8(1): 13-7.

7. Uluğ M, Can-Uluğ N, Selek Ş. Akut brusellozlu hastalarda akut faz reaktanlarının düzeyi. Klimik Dergisi 2010; 23(2): 48-50.

8. Ariza J, Bosilkovski M, Cascio A, Colmenero JD, Corbel MJ, Falagas ME, et al. Perspectives for the treatment of brucellosis in the $21^{\text {st }}$ century: the loannina recommendations. PLoS Med 2007; 4(12): e317.

9. Ariza J, Pujol M, Valverde J, Nolla J, Rufi G, Viladrich P, et al. Brucellar sacroiliitis: findings in 63 episodes and current relevance. Clin Infect Dis 1993;16(6):761-5.

10. Aydoslu B, Celik A, Kuloğlu F, Tansel O, Akata F, Tuğrul M. Evaluation of brucellosis patients in Trakya University Hospital. Mikrobiyol Bul. 2006; 40(3): 257-63.

11. Ruiz-Mesa J, Sanchez-Gonzalez J, Reguera J, Martin L, Lopez-Palmero S, Colmenero J. Rose Bengal test: diagnostic yield and use for the rapid diagnosis of human brucellosis in emergency departments in endemic areas. Clin Micro and Infect 2005; 11(3): 221-5.

12. Dean AS, Crump L, Greter H, Hattendorf J, Schelling E, Zinsstag J. Clinical manifestations of human brucellosis: a systematic review and meta-analysis. PLoS Negl Trop Dis 2012; 6(12): e1929.

13. Buzgan T, Karahocagil MK, Irmak H, Baran Al, Karsen H, Evirgen O, et al. Clinical manifestations and complications in 1028 cases of brucellosis: a retrospective evaluation and review of the literature. Int J Infect Dis 2010; 14(6): e469-e78.

14. Togan T, Ciftci O, Turan H, Narci H, Gullu H, Arslan H. Could there be an association between chronic brucellosis and endothelial damage? J Infect Dev Ctries 2015; 9(01): 048-54.

15. Hielpos MS, Ferrero MC, Fernández AG, Bonetto J, Giambartolomei GH, Fossati CA, et al. CCL20 and betadefensin 2 production by human lung epithelial cells and macrophages in response to Brucella abortus infection. PloS one 2015; 10(10): e0140408.

16. Garcia P, Yrivarren J, Argumans C, Crosby E, Carrillo C, Gotuzzo E. Evaluation of the bone marrow in patients with brucellosis. Clinico-pathological correlation. Enferm Infecc Microbiol Clin 1990; 8(1): 19.

17. Xie S, Zhou Y, Zheng R, Zuo W, Lu X, Wang Y, et al. Brucella-induced thrombocytopenia: a retrospective study of 16 patients. J Int Med Res 2019; 47(7): 3008-13.

18. Tsolia M, Drakonaki S, Messaritaki A, Farmakakis T, Kostaki M, Tsapra H, et al. Clinical features, complications and treatment outcome of childhood brucellosis in central Greece. J Infect 2002; 44(4): 257-62.

19. Bozdemir ŞE, Altıntop YA, Uytun S, Aslaner H, Torun YA. Diagnostic role of mean platelet volume and neutrophil to lymphocyte ratio in childhood brucellosis. The Korean J Intern Med 2017; 32(6): 1075.

20. Sen P, Demirdal T, Nemli SA. Predictive Value of Inflammation Markers in Brucellosis. Arch Iranian Med 2019; 22(11): 640-5.

21. Küçükbayrak A, Taş T, Tosun M, Aktaş G, Alçelik A, Necati Hakyemez I, et al. Could thrombocyte parameters be an inflammatory marker in the brucellosis. Med Glas 2013; 10(1).

22. Tekin R, Aktar F, Yılmaz K, Tekin S, Ayaz C. Comparison of inflammatory markers between adult and pediatric brucellosis patients. Rev Soc Bras Med Trop 2020; 53(1). 